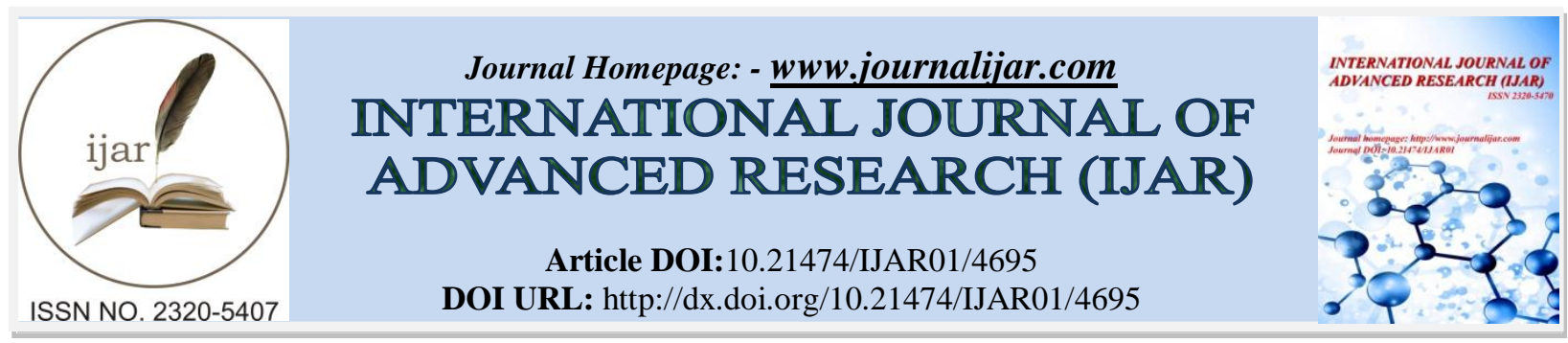

RESEARCH ARTICLE

\title{
EVALUATION OF ELITE SWEETPOTATO GENOTYPES FOR RESISTANCE TO SWEETPOTATO VIRUS DISEASE IN SOUTHERN ETHIOPIA.
}

Shiferaw Mekonen, Fekadu Gurmu and Tesfaye Tadesse.

South Agricultural Research Institute, Hawassa Research Center, P.O. Box 06, Hawassa, Ethiopia.

\section{Manuscript Info}

\section{Manuscript History}

Received: 1 May 2017

Final Accepted: 3 June 2017

Published: July 2017

Key words:-

Elite genotypes, resistance, root yield, serological test, sweetpotato virus disease.

\section{Abstract}

Sweetpotato is commonly grown in the south, south western and eastern parts of Ethiopia. The production trend of sweetpotato in Ethiopia is increasing in terms of area and volume of production and the country has very suitable climatic and edaphic conditions for its production. However, the productivity of the crops is very low as compared to its potential. Sweetpotato virus disease (SPVD) is one of the major problems which limit sweetpotato production and productivity, particularly in southern Ethiopia. Although different sweetpotato varieties have been released in Ethiopia, there is no variety which is resistant to the disease. Therefore, field experiment was conducted to identify SPVD resistant sweetpotato varieties under field conditions at Hawassa, Dilla and Halaba districts in southern Ethiopia during 2014-2015 cropping seasons. Eleven elite genotypes advanced from previous screening trial, two previously released varieties, one currently released variety (Mae), a susceptible variety (Guntute) and one local check were evaluated using a randomized complete block design with three replications. Variety Guntute was used as inoculum source and disease spreader during the study. Through visual assessment and serological test, only four genotypes have showed resistant reaction to the common SPVDs. The remaining 12 genotypes were infected with at least one of the major virus types (sweetpotato feathery mottle virus or sweetpotato chlorotic stunt virus). The four sweetpotato genotypes that were identified as resistant to SPVD were TIS-8250-1, TIS-70357-2, CN-1754-5, and CN-17526. These genotypes yielded 49.2, 45.3, 46.8 and $46.6 \mathrm{t} \mathrm{ha}^{-1}$, respectively, with yield advantage of 262.4 to $283.3 \%$ over the local check and 43 to $56 \%$ over the standard check. The genotypes are promising for registration as a variety after verification and can be recommended for direct production as well as donor parents for breeding program aiming at development of sweetpotato varieties resistant to SPVD.

Copy Right, IJAR, 2017,. All rights reserved.

\section{Introduction:-}

Sweetpotato [Ipomoea batatas L. (Lam)] is commonly grown around densely populated areas in the south, south western and eastern parts of Ethiopia. About 81,000 ha of arable lands in Ethiopia are covered by sweetpotato 
(CSA, 2012). South Nation, Nationalities and Peoples' Regional States (SNNPRS) is the major sweetpotato producing region followed by Oromia. It constitutes about $47.2 \%$ of the total sweetpotato production of the country (CSA, 2012).

Although the production trends of sweetpotato in Ethiopia is increasing in terms of area and yields and the country has very suitable climatic and edaphic conditions for its production, the national average storage root yield of sweetpotato in Ethiopia is quite low $\left(<10 \mathrm{t} \mathrm{ha}^{-1}\right)$ as compared to the world average ranging between 30 and $73 \mathrm{t} \mathrm{ha}{ }^{-1}$ (Hall and Harmon, 1989).

Sweetpotato is constrained by numerous factors such as disease and insect, moisture stress (drought), decline in soil fertility, poor crop management practices, lack of access to disease free vines of improved varieties are the major problems. Among the factors contributing to yield reductions in sweetpotato, insects and diseases are the major, resulting in yield reduction as high as 98\% (Kapinga et al., 2007, Gurmu et al, 2015).

Plant diseases caused by viruses, fungi and bacteria are responsible for the escalated economic losses of sweetpotato worldwide. Among the disease causing pathogens, viral diseases are the main constraints of sweetpotato production and productivity (Njeru etal., 2004). Viruses often occur in multiple infections in the field with the most commonly encountered combination being that between sweetpotato feathery mottle virus (SPFMV) and sweetpotato chlorotic stunt virus (SPCSV). This dual infection is responsible for the severe sweetpotato virus disease (SPVD) which has been reported to be the major viral disease in East Africa (Mukasa et al., 2003).

In Ethiopia, the frequent occurrence and incidence of SPFMV, sweetpotato virus G (SPVG), SPCSV and Sweetpotato virus 2 (SPV2), either singly or in combination in infecting the crop has been reported by different researchers (Tamru, 2004; Abraham, 2010; Teddy et al., 2011; Shiferaw et al., 2016). Shiferaw et al. (2016) reported discovery of six new viruses, namely sweetpotato latent virus (SPLV), sweetpotato caulimo-like virus (SPCaLV), sweetpotato chlorotic fleck virus (SPCFV), cucumber mosaic virus (CMV), flexious rod virus (C-6) and sweetpotato mild speckling virus (SPMSV) from samples collected from germplasm screening trial, vine multipliers and farmers field of sweetpotato production areas in the SNNPRS of Ethiopia. The prevalence of the disease was studied by collecting 235 symptomatic samples from eight zones of Ethiopia. Of the collected samples $68.5 \%$ of the samples reacted positive with antisera of one or more viruses. In addition the frequency of individual virus SPFMV (56.6\%), SPCSV (48.9\%) and, SPVG (11.9\%) and in mixed infection of SPFMV and SPCSV (37\%) were detected (Teddy et al., 2011). This indicated the importance and prevalence of viral diseases in Ethiopia and its implication on yield reduction, since sweetpotato is highly sensitive to virus infection.

In Ethiopia, the root yield reduction due to the synergistic infection of SPFMV and SPCSV was reported to be $37 \%$ (Tesfaye et al., 2013). Mukasa et al. (2003) also reported that yield losses due to virus infection can reach 56-98\% in Africa.

Disease management strategies such as cultural practices, phytosanitary measures, control of vectors and deployment of genetic resistance to prevent or limit the extent of damage have been recommended. Among these, use of disease resistant genotypes is an ideal option in terms of effectiveness and sustainability for managing any plant disease in general and sweetpotato virus disease (SPVD) in particular (Maule et al., 2007). The use of virus resistant sweetpotato varieties to reduce the impact of SPVD under farmer's field has been reported by Miano, et al. (2008). However, there is no any resistant variety so far registered to be used as integrated disease management component in Ethiopia. Hence, the objective of the current study was to evaluate the reaction of elite sweetpotato genotypes to SPVD and to identify resistant genotypes for recommendation or for further improvement works.

\section{Materials and Methods:-}

\section{Description of the study Sites:-}

The study was conducted at Hawassa, Dilla and Halaba in SNNPR, in 2014 and 2015 main rainy seasons. The locations are the known hot spot areas for sweetpotato viruses, where the two important viruses infecting sweetpotato, namely SPFMV and SPCSV are equally prevalent.

\section{Experimental design and Management:-}

Eleven promising genotypes that had been advanced from previous trials, TIS-8441-6, TIS-82/0602-12, TIS82/0602-2, TIS-9068-6, TIS-82/0602-6,TIS-8250-1,TIS70357-2, CN-2063-6, CN-2066-2,CN-1754-5 and CN-1752- 
6, released varieties namely, Mae (standard check), Becule-type-1, Berkume and susceptible variety (Guntute) and one local check were used for the study.

The experiment was laid out in a randomized complete block design (RCBD) with three replications. Vines were planted in four rows on a plot size of $3 \mathrm{~m} \mathrm{x} 2.4 \mathrm{~m}$ and were spaced at 60 and $30 \mathrm{~cm}$ between rows and plants, respectively. The known susceptible variety Guntute, (Shiferaw et al., 2014), was planted around the experimental plot to serve as a source of inoculums in the trial. A recently released variety in Ethiopia (Mae) and one local variety were used as improved check and local check, respectively. All the recommended agronomical practices were used as deemed necessary.

For further verification of the presence/absence of viruses, each genotype was planted in pots in a net tunnel andinfected Guntute and Awassa-83 varieties having white flies and aphids introduced in the net tunnel. Finally, virus detection was conducted through serological test, using nitrocellulose membrane enzyme-linked immune sorbent assay (NCM-ELISA) (Aritua et al., 1998).

\section{Virus Detection:-}

Three months after planting, symptomatic leaf samples were collected using plastic bag from the top, middle and basal parts of the stem for virus detection in the laboratory. The collected samples from each genotype were sent to Areka Agricultural Research Center biotechnology laboratory for virus detection. NCM-ELISA was used for the serological test. Each sample was tested against antibodies of 10 viruses which were reported as economically important, namely, SPFMV, SPVG, SPCSV, C-6, SPCaLV, SPCFV, SwPLV, Sweetpotato mild mottle virus (SPMMV), SPMSV and CMV.

\section{Data Collection:-}

Assessment of disease incidence and severity through scoring:-

Visual assessment was started two months after planting and data collected at 15 days interval until the crop gets matured. Presence and absence of viruses was identified in the field using biological property related to virus interaction with its host. Accordingly, severity and incidence of disease was recorded using the leaf and plant color and size deviation from normal appearance (purple, mosaic, vein clearing) and deformation of leaf size and shape to record virus-positive samples (Gutierrez et al., 2003). Severity was recorded using a 1-5 scale; where 1 = no visible symptoms, 2 = mild symptoms (a few local lesions on a few leaves), 3 = moderate symptoms (mosaic symptoms on leaves), 4 = severe symptoms (mosaic symptoms with plant stunting) and $5=$ very severe symptoms of purpling/yellowing or mosaic on leaves, severe leaf distortion, reduced leaf size and severe stunting (Mwanga et al., 2013; Njeru et al., 2004). Finally, the mean of five recorded severity data were used to estimate the virus reaction across locations and years.

\section{Storage Root:-}

Data related to marketable root yield (MY) and unmarketable root yield (UMY) was recorded by harvesting two central rows in each plot. Total storage roots $\left(\right.$ tha $\left.^{-1}\right)$ were sorted as unmarketable (blighted, rotten, deformed and unacceptable size) and marketable.

\section{Data Analysis:-}

The data on storage root yield (marketable, unmarketable and total yield), and root diameter were subjected to analysis of variance (ANOVA) using the following statistical model.

$$
Y_{i j k l}=\mu+G_{i}+E_{j}+R_{k(j)}+G E_{i j}+\varepsilon_{i j k l}
$$

Where: $\mathrm{Y}_{\mathrm{ijkl}}$ is observed value of genotype $i$ replication $k$ of environment $j, \mu$ is grand mean, $\mathrm{G}_{\mathrm{i}}$ is effect of genotype $i, \mathrm{E}_{\mathrm{j}}$ is environment or location effect, $\mathrm{GE}_{\mathrm{ij}}$ is the interaction effect of genotype $i$ with environment $j, \mathrm{R}_{\mathrm{k}(\mathrm{j})}$ is the effect of replication $k$ in environment $j, \epsilon_{\mathrm{ijkl}}$ is error (residual) effect of genotype $i$ in replication $k$ of environment $j$.

Means were separated following Fisher's protected least significant difference test at 5\% significance level (LSD 5\%). All analyses were done with the Statistical Analysis System (SAS) version 9.1 (SAS Institute Inc., 2003.). 


\section{Results and Discussion:-}

\section{Reaction of sweetpotato genotypes to major sweetpotato viruses:-}

There was disease infestation in the study period. In all locations, the susceptible check was infected with SPVD during the study period. Most of the varieties showed consistent disease severity score during the study across the three locations. The mean disease severity score was almost similar for both years, 2014 and 2015. There was higher SPVD severity and incidence at Dilla and Hawassa than Halaba. This was due to the presence of insect vectors on sweetpotato fields and the conducive environment for multiplication of vectors in the two sites.

\section{Virus Detection:-}

The result of the serological test indicated that of all the genotypes samples tested, only four genotypes showed negative reaction to the test. The remaining tested genotypes samples, including the checks, have showed positive reaction at least for one type of viruses (Table 1). SPFMV and SPCSV were detected from the positive samples even though the occurrence of the viruses in the samples varied among tested genotypes. These two viruses were identified from samples of TIS-8441-6, TIS-82/0602-12, TIS-82/0602-2, CN-2063-6, local variety and Guntute genotypes. Karyeija et al. (2000) indicated that SPVD is a major production constraint of sweetpotato in Africa and is commonly attributed to the synergistic interaction of the SPFMV and SPCSV in mixed infection. In the remaining positive samples (genotypes), only one virus, SPFMV, was detected (Table 1), which is the common virus in sweetpotato growing areas of Ethiopia (Tamru, 2004; Abraham, 2010; Teddy et al., 2011; Shiferaw et al., 2016).

Table 1:- Reaction of elite sweetpotato genotypes to major sweetpotato viruses detected by ELISA in 2015 cropping season

\begin{tabular}{|c|c|c|c|c|c|c|c|c|c|c|}
\hline \multirow{2}{*}{ Genotypes } & \multicolumn{10}{|c|}{ Type of virus } \\
\hline & SPFMV & SPVG & $\begin{array}{l}\text { SPCS } \\
\text { V }\end{array}$ & C-6 & SPCALV & $\begin{array}{l}\text { SPCF } \\
\mathrm{V}\end{array}$ & SwPIV & SPMSV & $\begin{array}{l}\text { SPMM } \\
\text { V }\end{array}$ & $\begin{array}{l}\mathrm{CM} \\
\mathrm{V}\end{array}$ \\
\hline TIS-8441-6 & + & - & + & - & - & - & - & - & - & - \\
\hline $\begin{array}{l}\text { TIS-82/0602- } \\
12\end{array}$ & + & - & + & - & - & - & - & - & - & - \\
\hline TIS-82/0602-2 & + & - & ++ & - & - & - & - & - & - & - \\
\hline TIS-9068-6 & + & - & - & - & - & - & - & - & - & - \\
\hline TIS-82/0602-6 & ++ & - & + & - & - & - & - & - & - & - \\
\hline TIS-8250-1 & - & - & - & - & - & - & - & - & - & - \\
\hline TIS-70357-2 & - & - & - & - & - & - & - & - & - & - \\
\hline Mae & + & - & - & - & - & - & - & - & - & - \\
\hline CN-2063-6 & + & - & + & - & - & - & - & - & - & - \\
\hline CN-2066-2 & + & - & - & - & - & - & - & - & - & - \\
\hline CN-1754-5 & - & - & - & - & - & - & - & - & - & - \\
\hline CN-1752-6 & - & - & - & - & - & - & - & - & - & - \\
\hline Becule-type-1 & ++ & - & - & - & - & - & - & - & - & - \\
\hline Berkume & ++ & - & - & - & - & - & - & - & - & - \\
\hline Local & ++ & 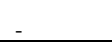 & ++ & - & - & - & - & - & - & - \\
\hline Guntute & ++ & & +++ & - & - & - & - & - & - & - \\
\hline
\end{tabular}

$*_{-}=$negative; $+=$low color intensity/weak reaction/;

$++=$ Medium color intensity/medium reaction/; $+++=$ strong colour intensity/strong reaction/ by ELISA to the respective virus color.

SPFMV = Sweetpotato feathery mottle virus; $\mathrm{SPVG}=$ Sweetpotato virus G; SPCSV $=$ Sweetpotato chlorotic stunt virus; C-6 virus; SPCaLV = Sweetpotato caulimo-like virus; SPCFV= Sweetpotato chlorotic flecks virus; SPLV= Sweetpotato latent virus; SPMSV= Sweetpotato mild speckling virus; SPMMV= Sweetpotato mild mottle virus; $\mathrm{CMV}=$ Cucumber mosaic virus.

\section{Disease reaction and severity:-}

On the bases of disease severity rating scale, the reaction of the genotypes is grouped into four categories. These are resistant, moderately resistant, moderately susceptible and susceptible. Out of the tested genotypes, 4 genotypes (25\%) namely, TIS-8250-1, TIS-70357-2, CN-1754-5 and CN-1752-6 were found to be virus free across the test locations and showed immune reaction. This finding is in agreement with the previous works of Gibson et al. (2000) 
who reported that some landraces of sweetpotato in sub-Saharan African countries are resistant to SPVD. Three genotypes (19\%), Mae, CN-2063-6 and CN-2066-2 showed moderately resistant reaction with disease severity score of 1.72, 1.33 and 1.89, respectively while 4 genotypes (25\%), TIS-82/0602-6, TIS 9068-6, TIS-8441-6, TIS82/0602-12, and Berkume showed moderately susceptible reaction with disease severity score of $2.89,2.55,2.78$ and 2.44 respectively. The remaining 4 genotypes (25\%), Becule-type-1, TIS-82/0602-2, local cultivar and Guntute showed susceptible reaction with disease severity score of 3.55, 4.22, 3.45 and 4.16, respectively (Table 2).The result indicated the presence of variability in sweetpotato genotypes against virus infection. Some plants might be resistant in one environments and affected in other environment due to presence of different viral strains. Mwanga et al. (2002b) reported that resistant varieties in West Africa and Peru succumbed viral diseases in East Africa, possibly due to different strains of viruses

Table 2:-The mean virus disease severity (1-5) of sweetpotato genotypes evaluated across locations and over years

\begin{tabular}{|c|c|c|c|c|c|c|c|c|c|}
\hline \multirow[t]{2}{*}{ Genotypes } & \multicolumn{4}{|l|}{2014} & \multicolumn{4}{|l|}{2015} & \multirow{2}{*}{$\begin{array}{l}\text { Over all } \\
\text { mean }\end{array}$} \\
\hline & Dilla & Hawassa & Halaba & mean & Dilla & Hawassa & Halaba & mean & \\
\hline TIS-841-6 & 2.00 & 3.00 & 3.00 & 2.67 & 2.67 & 3.33 & 2.67 & 2.89 & 2.78 \\
\hline $\begin{array}{l}\text { TIS-82/0602- } \\
12\end{array}$ & 2.33 & 2.33 & 3.00 & 2.55 & 3.00 & 2.00 & 2.00 & 2.33 & 2.44 \\
\hline TIS-82/0602-2 & 3.67 & 4.33 & 4.33 & 4.11 & 5.00 & 4.00 & 4.00 & 4.33 & 4.22 \\
\hline TIS-9068-6 & 2.33 & 2.33 & 3.00 & 2.55 & 3.00 & 2.67 & 2.00 & 2.56 & 2.55 \\
\hline TIS-82-0602-6 & 2.67 & 2.33 & 4.33 & 3.11 & 2.67 & 3.00 & 2.33 & 2.67 & 2.89 \\
\hline TIS-8250-1 & 1.00 & 1.00 & 1.00 & 1.00 & 1.00 & 1.00 & 1.00 & 1.00 & 1.00 \\
\hline TIS-70357-2 & 1.00 & 1.00 & 1.00 & 1.00 & 1.00 & 1.00 & 1.00 & 1.00 & 1.00 \\
\hline Mae & 1.67 & 2.33 & 1.33 & 1.78 & 1.33 & 2.33 & 1.33 & 1.66 & 1.72 \\
\hline CN-2063-6 & 1.33 & 1.00 & 1.00 & 1.11 & 1.00 & 2.33 & 1.33 & 1.55 & 1.33 \\
\hline CN-2066-2 & 2.33 & 2.00 & 1.00 & 1.78 & 2.00 & 2.33 & 1.67 & 2.00 & 1.89 \\
\hline CN-1754-5 & 1.00 & 1.00 & 1.00 & 1.00 & 1.00 & 1.00 & 1.00 & 1.00 & 1.00 \\
\hline CN-1752-6 & 1.00 & 1.00 & 1.00 & 1.00 & 1.00 & 1.00 & 1.00 & 1.00 & 1.00 \\
\hline Becule-type-1 & 3.33 & 3.00 & 3.00 & 3.50 & 3.00 & 4.33 & 3.50 & 3.67 & 3.55 \\
\hline Bercume & 3.67 & 1.67 & 3.33 & 2.89 & 3.00 & 3.00 & 2.67 & 2.89 & 2.89 \\
\hline Local & 2.33 & 3.00 & 3.33 & 2.88 & 3.00 & 3.67 & 3.00 & 3.22 & 3.45 \\
\hline Guntute & 4.00 & 3.67 & 5.00 & 4.22 & 4.33 & 3.00 & 5.00 & 4.11 & 4.16 \\
\hline Mean & 2.23 & 2.19 & 2.48 & 2.32 & 2.38 & 2.50 & 2.22 & 2.37 & 2.37 \\
\hline
\end{tabular}

$1=$ resistant, $1.1-2=$ moderately resistant, $2.1-3=$ moderately susceptible, $3.1-5=$ susceptible

Mean performance of the genotypes for marketable root yield across the three locations:-

There was significant difference $(\mathrm{p}<0.01)$ between genotypes for marketable root yield. High mean marketable root yields of 49.2, 45.3, 46.8 and $46.6 \mathrm{t} \mathrm{ha}^{-1}$ were obtained from TIS-8250-1, TIS-70357-2, CN-1754-5 and CN-1752-6, respectively. These genotypes provided yield advantage of $262.4-283.3 \%$ and $43-56 \%$ over local check and standard check, respectively (Table 3). All high yielder genotypes were resistant to SPVD as indicated in Table 1 and 2 .

On the other hand, low marketable root yields were obtained from susceptible genotypes such as TIS-82/0602-2 (6.5 $\left.\mathrm{t} \mathrm{ha}^{-1}\right)$ and Becule-type-1 (6.0 $\left.\mathrm{t} \mathrm{ha}^{-1}\right)$. The significant yield difference observed between resistant and susceptible genotypes might be mainly due to the effect of virus on the susceptible ones. The current result is in line with the previous works reported by Stephan et al. (2013) who reported that variation among sweetpotato varieties in terms of virus resistance is expressed by increased yield and decreased quality loss of tested varieties.

The moderately resistant genotypes, Mae, CN-2063-6 and CN-2066-2 gave root yields of 31.5, 11.8 and $10.3 \mathrm{t}$ ha ${ }^{-1}$, respectively. whereas moderately susceptible genotypes such as TIS-8441-6, TIS-82/0602-12, Berkume, yielded 8.1 $\mathrm{t} \mathrm{ha}^{-1,}, 8.7 \mathrm{ha}^{-1}$, and $9.5 \mathrm{t} \mathrm{ha}^{-1}$, respectively. The observed yield differences among moderately resistant genotypes in this study might be due to genetic differences since all genotypes showed similar disease reaction as well received equal management.

The mean yield performance of each location in 2014 was higher than 2015 cropping season. This was because there was no enough rainfall during 2015 cropping season in all of the locations. 
Table 3:-Total storage root performance of sweetpotato clones tested across locations and years.

\begin{tabular}{|c|c|c|c|c|c|c|c|c|c|c|c|}
\hline \multirow[b]{2}{*}{ 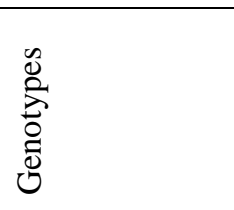 } & \multicolumn{4}{|c|}{2014} & \multicolumn{4}{|c|}{2015} & \multirow[b]{2}{*}{ 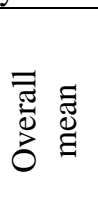 } & \multirow{2}{*}{ 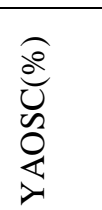 } & \multirow{2}{*}{ 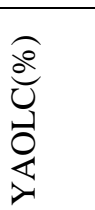 } \\
\hline & $\begin{array}{l}\widetilde{J} \\
\tilde{W} \\
\tilde{\Xi} \\
\tilde{J}\end{array}$ & $\stackrel{\tilde{\sigma}}{\bar{\nabla}}$ & $\begin{array}{l}\frac{\pi}{\widetilde{\Xi}} \\
\frac{\pi}{\tilde{I}}\end{array}$ & $\stackrel{\Xi \Xi}{\Sigma}$ & 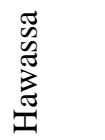 & $\stackrel{\tilde{\Xi}}{\bar{\sigma}}$ & $\begin{array}{l}\frac{\pi}{\mathbb{\pi}} \\
\frac{\pi}{\pi}\end{array}$ & $\stackrel{\widetilde{\varpi}}{\sum_{\Sigma}^{ \pm}}$ & & & \\
\hline TIS-8441-6 & 16.67 & 7.96 & 9.81 & 11.48 & 5.06 & 6.02 & 3.33 & 4.8 & 8.14 & -74.2 & -36.6 \\
\hline TIS-82/0602-12 & 10.37 & 17.22 & 10.18 & 12.59 & 4.97 & 7.87 & 1.85 & 4.9 & 8.74 & -72.3 & -31.9 \\
\hline TIS-82/0602-2 & 9.47 & 7.78 & 9.63 & 8.96 & 3.71 & 6.02 & 2.22 & 3.98 & 6.47 & -79.5 & -49.6 \\
\hline TIS-9068-6 & 15.37 & 19.07 & 14.81 & 16.42 & 7.5 & 7.07 & 2.49 & 5.69 & 11.05 & -65 & -13.9 \\
\hline TIS-82/0602-6 & 19.63 & 16.48 & 8.70 & 14.94 & 13.43 & 4.72 & 8.88 & 9.01 & 11.97 & -62 & -6.7 \\
\hline TIS-8250-1 & 57.36 & 55.94 & 49.82 & 54.37 & 47.03 & 47.9 & 37.04 & 43.98 & 49.18 & 56 & 283.3 \\
\hline TIS70357-2 & 50.19 & 53.52 & 51.85 & 51.85 & 41.39 & 36.57 & 38.24 & 38.73 & 45.29 & 43.6 & 253 \\
\hline Mae & 37.04 & 32.77 & 38.89 & 36.23 & 41.48 & 19.07 & 19.91 & 26.82 & 31.53 & 0 & 145.8 \\
\hline CN-2063-6 & 13.7 & 10 & 12.59 & 12.1 & 5.18 & 13.1 & 16.2 & 11.49 & 11.8 & 62.6 & -8 \\
\hline CN-2066-2 & 12.07 & 16.29 & 11.85 & 13.4 & 8.24 & 9.26 & 4.07 & 7.19 & 10.3 & 67.3 & -19.7 \\
\hline CN-1754-5 & 55.56 & 54.63 & 53.15 & 54.45 & 46.76 & 32.4 & 38.33 & 39.17 & 46.81 & 48.5 & 264.8 \\
\hline CN-1752-6 & 58.7 & 55.37 & 49.81 & 54.63 & 41.2 & 38.89 & 35.37 & 38.49 & 46.56 & 47.7 & 262.9 \\
\hline Becule-type-1 & 7.77 & 6.43 & 8.89 & 7.7 & 6.2 & 3.7 & 3.24 & 4.38 & 6.04 & -80.8 & -52.9 \\
\hline Berkume & 17.96 & 7.22 & 11.11 & 12.1 & 6.29 & 8.98 & 5.35 & 6.87 & 9.49 & -69.9 & -26 \\
\hline Local & 18.33 & 14.81 & 12.96 & 15.37 & 5.92 & 10.37 & 14.61 & 10.3 & 12.83 & -59.3 & 0 \\
\hline Guntute & 16.29 & 24.45 & 10.18 & 16.97 & 7.41 & 9.54 & 4.07 & 7.01 & 11.99 & -74.2 & -6.5 \\
\hline Mean & 26.1 & 25 & 22.8 & 24.6 & 18.2 & 16.3 & 14.7 & 16.4 & 20.5 & & \\
\hline LSD (5\%) & 13.4 & 10.9 & 7.2 & 6.1 & 9 & 7.9 & 9.5 & 5 & 3.9 & & \\
\hline CV (\%) & 31.8 & 25.3 & 19 & 26.4 & 33.1 & 26.2 & 38.6 & 32.3 & 28.9 & & \\
\hline $\mathbf{R}^{2}$ & 89.9 & 92.3 & 96.4 & 92.6 & 91.3 & 95.5 & 90.7 & 92.9 & 93.2 & & \\
\hline
\end{tabular}

$*$ YAOSC $=$ Yield advantage over standard check (\%), YAOLC $=$ Yield advantage over local check $(\%)$

\section{Conclusion and Recommendation:-}

Four genotypes namely, TIS-8250-1, TIS-70357-2, CN-1754-5 and CN-1752-6 were selected based on their resistance to SPVD and high root yield. These genotypes will be verified for release and registration. The output has an opportunity to increase productivity and to boost food security in the SNNPRS as well as in the country as a whole. Since the identified genotypes possess high levels of resistance, they can be used as sources of resistance to improve the susceptible but high yielding and popular varieties, such as Awassa-83 and local varieties through crossing. Guntute and TIS-82/0602-2 were found the most susceptible in the study and can be used as sources of inoculums in screening experiments for SPVD.

\section{Acknowledgments:-}

The authors thank the South Agricultural Research Institute for the logistical arrangements for execution of the field works.

\section{References:-}

1. Adane A. Associated viruses threatening sweetpotato improvement and production Ethiopia. African crop science journal 2010; 18: 207-213.

2. Aritua V, Adipala E, Carey EE, Gibson RW. The incidence of sweetpotato virus disease and virus resistance of sweetpotato grown in Uganda. Annals of Applied Biology 1998; 132: 399-411.

3. CSA. Agricultural sample survey 2012/2013. Report on area and production of major crops. Central Statistical Agency of Ethiopia, Addis Ababa, Ethiopia, 2013, p. 121.

4. CSA. Agricultural sample survey 2011/2012. Report on area and production of major crops. Central Statistical Agency of Ethiopia, Addis Ababa, Ethiopia, 2012, p. 143.

5. Gibson RW, Alicai T, Carey EE, Seal SE, Vetten HJ. Symptoms, etiology and serological analysis of sweetpotato virus disease in Uganda. Plant Pathology 1998; 47: 95-102.

6. Gurmu F, Hussein S, Laing M. Diagnostic assessment of sweetpotato production in Ethiopia : constraints, postharvest handling and farmers' preferences. Research on Crops 2015; 16(1): 104-115. 
7. Gutierrez DL, Fuentes S, Salazar LF. Sweetpotato Virus Disease (SPVD): Distribution, Incidence and effect on Sweetpotato yield in Peru. Plants Disease 2003; 87:297-302.

8. Hall MR, Harmon SA. Coastal red sweetpotato. Hort Science 1989; 24:196-177.

9. Juo ASR. Selected method for soil and plant analysis. Manual Series, No.1. Ibadan, Nigeria, IITA, 1983.

10. Kapinga R, Ortiz O, Ndunguru J, Omiat E, Tumwegamire S. Hand book of Sweetpotato Integrated Crop Management: Research Outputs and Programs for East Africa, 2007.

11. Karyeija RF, Kreuze JF, Gibson RW, Valkonen JPT. Synergistic interactions of a potyvirus and a phloemlimited crinivirus in sweetpotato plants. Virology 2000; 269:26-36.

12. Mukasa SB, Rubaihayo PR, Valkonen JPT. Incidence of Viruses and Virus-like Diseases in Sweetpotato in Uganda. Plant Disease 2003; 87:336-340.

13. Maule AJ, Caranta C, Boulton MT. Sources of natural resistance to plant virus: status and prospects. Molecular plant pathology 2007; 223-231.

14. Miano D, Labonte D, Clark C. Identification of molecular markers associated with sweetpotato resistance to sweetpotato virus disease in Kenya. Euphytica 2008; 160:15-24.

15. Mwanga ROM, Yencho CGC, Gibson RW, Moyer JW. Methodology for inoculating sweetpotato virus disease: discovery of tip dieback, and plant recovery and reversion in different clones. Plant Disease 2013; 97:30-36.

16. Mwanga R, Yencho G, Moyer JW. Diallel analysis of sweetpotatoes for resistance to sweetpotato virus disease. Euphytica 2002; 128:237-248.

17. Njeru RW, Mburu MW, Cheramgoi E, Gibson RW, Obudho E, Yobera D. Studies on the physiological effects of viruses on sweetpotato yield in Kenya. Annals of Applied Biology 2004; 145: 71-76.

18. Shiferaw M, Fikre H, Fekadu G, Elias U, Sweetpotato Diseases Research in Ethiopia. International Journal of Agriculture Innovations and Research 2014; 2:933-938.

19. Shiferaw M, Berhanu B, Tesfaye T, Fekadu G. Evaluation of exotic and locally adapted sweetpotato cultivars to major viruses in Ethiopia. Greener Journal of Agricultural Sciences 2016; 6(2): 069-078.

20. Stephan N, Hussein S, Julia S, Kido M. Review of sweetpotato breeding for resistance to sweetpotato virus disease and improved yield: Progress and challenges. African Journal of Agricultural Research 2013; $8(25): 3202-3215$.

21. Tamru A. Characterization of viruses of hot pepper (Capsicum spp.) and sweetpotato (Ipomea batatas) from Ethiopia. Doctorial dissertation. University of Bonn, 2004; pp. 126.

22. Tesfaye T, Fikre H, Mesele G. Prevalence, incidence and distribution of sweetpotato virus: Its effect on the yield of sweetpotato in Southern Region of Ethiopia. International Journal of Science and Research 2013; 2(1):591-595.

23. Tsakama M, Mwangwela AM, Manani TA, Mahungu NM. Physicochemical and pasting properties of starch extracted from eleven sweetpotato varieties. African Journal of Food Science and Technology 2010; 1: 90-9. 